\title{
Targeting purinergic receptors to attenuate inflammation of dry eye
}

\author{
Jia-Ning Wang ${ }^{1} \cdot$ Hua Fan ${ }^{1} \cdot$ Jian-Tao Song ${ }^{1}$ \\ Received: 31 October 2021 / Accepted: 4 February 2022 / Published online: 26 February 2022 \\ (c) The Author(s) 2022
}

\begin{abstract}
Inflammation is one of the potential factors to cause the damage of ocular surface in dry eye disease (DED). Increasing evidence indicated that purinergic $\mathrm{A}_{1}, \mathrm{~A}_{2 \mathrm{~A}}, \mathrm{~A}_{3}, \mathrm{P} 2 \mathrm{X} 4, \mathrm{P} 2 \mathrm{X} 7, \mathrm{P} 2 \mathrm{Y}_{1}, \mathrm{P} 2 \mathrm{Y}_{2}$, and $\mathrm{P} 2 \mathrm{Y}_{4}$ receptors play an important role in the regulation of inflammation in DED: $A_{1}$ adenosine receptor $\left(A_{1 R}\right)$ is a systemic pro-inflammatory factor; $A_{2 A R}$ is involved in the activation of the MAPK/NF-kB pathway; $A_{3 R}$ combined with inhibition of adenylate cyclase and regulation of the mitogen-activated protein kinase (MAPK) pathway leads to regulation of transcription; P2X4 promotes receptor-associated activation of pro-inflammatory cytokines and inflammatory vesicles; $\mathrm{P} 2 \mathrm{X} 7$ promotes inflammasome activation and release of pro-inflammatory cytokines IL-1 $\beta$ and IL-18; P2Y receptors affect the phospholipase C(PLC)/IP3/ $\mathrm{Ca}^{2+}$ signaling pathway and mucin secretion. These suggested that purinergic receptors would be promising targets to control the inflammation of DED in the future.
\end{abstract}

Keywords Dry eye disease $\cdot$ Purines $\cdot$ Purinergic receptors $\cdot$ Inflammation

Jia-Ning Wang a master student in China Academy of Chinese Medical Science, supervised by the corresponding author Dr. Jian-Tao Song since 2021. His research interest is focusing on the clinical treatment of ocular surface diseases.

Hua Fan a master student in China Academy of Chinese Medical Science, is supervised by the corresponding author Dr. Jian-Tao Song since 2020. Her research interest is focusing on the pathogenesis of ocular surface disease.
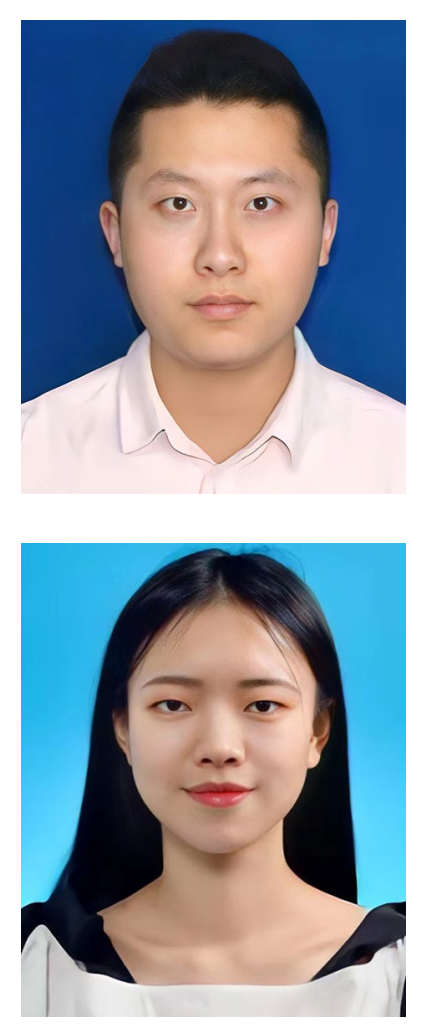

Jian-Tao Song

Jangts@163.com

1 Eye Hospital, China Academy of Chinese Medical Sciences,

Beijing, China 


\section{Introduction}

Dry eye disease (DED) is one of the most common ocular surface diseases in the world. DED is caused by a variety of etiologies. It is characterized by loss of tear film homeostasis with tear film instability and high osmolarity, ocular surface inflammation and injury, and neurosensory abnormalities [1]. The incidence of DED is increasing every year and has a serious impact on the physical and mental health of the population. The prevalence of DED ranges from 5.5 to $33.7 \%$ worldwide, over $30 \%$ in China [2]. DED has a great impact on patients' life and work and even leads to depression. The common clinical treatment method is artificial tears, which cannot solve the root of the problem, and the efficacy is difficult to guarantee. Therefore, it is important to understand the potential therapeutic targets of DED in order to develop effective treatment strategies.

Purinergic receptor was formally proposed as a medical term in 1978. There are four types of P1 receptors (adenosine $A_{1}, A_{2 A}, A_{2 B}$, and $A_{3}$ ), two types of $P 2$ receptors ( $P 2 X$ and $\mathrm{P} 2 \mathrm{Y}$ ), seven types of $\mathrm{P} 2 \mathrm{X}$ receptors ( $\mathrm{P} 2 \mathrm{X} 1-7)$, and eight types of $\mathrm{P} 2 \mathrm{Y}$ receptors $\left(\mathrm{P} 2 \mathrm{Y}_{1}, \mathrm{P}_{2} \mathrm{Y}_{2}, \mathrm{P}_{2} \mathrm{Y}_{4}, \mathrm{P}_{2} \mathrm{Y}_{6}, \mathrm{P}_{2} \mathrm{Y}_{11-14}\right)$. Adenosine triphosphate (ATP) binds to these receptors and induces cell-to-cell communication and propagation of inflammation [3]. ATP binds to $\mathrm{P} 2 \mathrm{X}$ receptors, which are ligand-dependent ion channels $\left(\mathrm{Na}^{+}, \mathrm{K}^{+}, \mathrm{Ca}^{2+}\right)$ to control rapid responses. ATP and adenosine diphosphate (ADP) activate $\mathrm{P} 2 \mathrm{Y}$ receptors; this is a second messenger system that acts through $\mathrm{G}$ proteins to control the inflammatory release of various neurotransmitters and hormones [4].

DED is an inflammatory disease that occurs at the ocular surface. The inflammatory components of DED include cells (lymphocytes, macrophages, and T cells etc. [5-7]) and mediators (Th1-related cytokines, matrix metalloproteinases, chemokines, and their receptors etc. [8-11]). Tear film instability, tear hyperpermeability, corneal/conjunctival apoptosis, and inflammation of the ocular surface can create a vicious cycle of inflammation. The relationship between purine receptors and DED is reflected in the widespread presence of purines in ocular tissues such as the cornea, conjunctiva, and lacrimal gland, which play a role in regulating their physiology and pathology [12] (Fig. 1). Purine receptors $\mathrm{P} 2 \mathrm{Y}_{1}, \mathrm{P}_{2} \mathrm{Y}_{2}, \mathrm{P}_{2} \mathrm{Y}_{4}$, and $\mathrm{P} 2 \mathrm{Y}_{6}$ have been found in corneal epithelial and endothelial cells [13-15]. The expression of purinergic receptors, especially the P2 receptor subtype, is associated with the activation of inflammatory vesicle complexes and the release of proinflammatory cytokines [16]. Adenosine receptors were also found to be highly expressed in inflammatory cells of the cornea [17, 18], and as a result, inflammatory factors act as signaling molecules that bind to their corresponding receptors and cause DED [19]. Undoubtedly, inflammation is one of the most important mechanisms of DED, and purinergic receptors are important pharmacological targets for inflammation therapy. The most widely used treatment for DED is artificial tears. Further treatment emphasizes immunosuppressive or anti-inflammatory drugs that act through the pro-secretory agent pathway with the aim of promoting tear production [20]. These drugs include purinergic $\mathrm{P}_{2} \mathrm{Y}_{2}$ receptor agonists, mucin secretion stimulants, and so on [21-24]. The therapeutic approach focuses on the underlying pathogenic pathways, which may provide better results. Therefore, in this review, we focus on the molecular mechanism of purine receptors as a potential therapeutic target for DED.

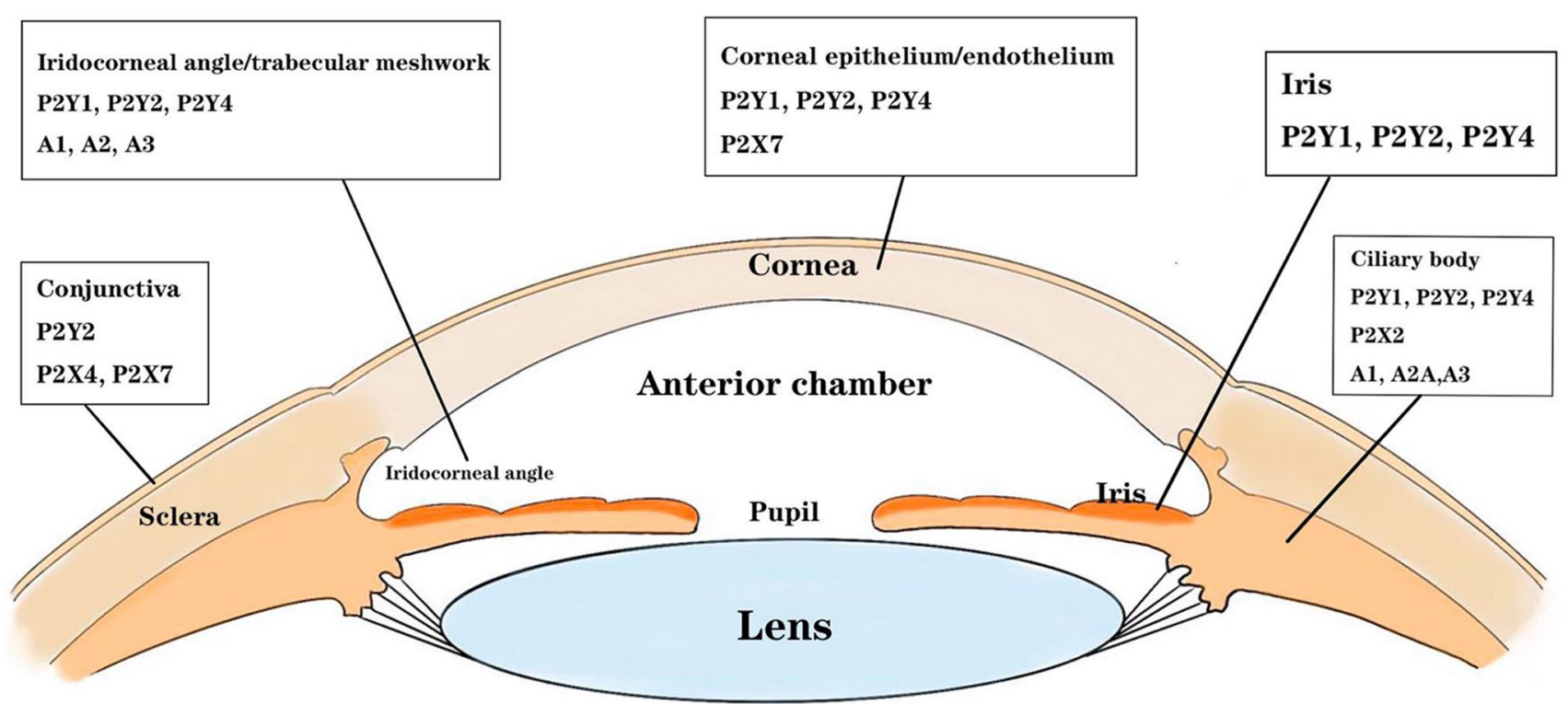

Fig. 1 Distribution of purinergic receptors in ocular surface structures 


\section{Adenosine receptors in inflammation}

Adenosine is an endogenous nucleoside that is widely distributed in the body and regulates a variety of functions. Among the $\mathrm{P} 1$ receptors, $\mathrm{A}_{1 \mathrm{R}}, \mathrm{A}_{2 \mathrm{AR}}$, and $\mathrm{A}_{3 \mathrm{R}}$ are mainly involved in the mechanism of inflammation regulation. The biological function of adenosine is mediated through the activation of different G-coupled receptors, $A_{1 R}, A_{2 A R}$, and $A_{3 R}$, which inhibit or promote the generation of cyclic adenosine monophosphate (cAMP) in multiple ways. $A_{1 R}$ and $A_{3 R}$ downregulate CAMP levels and inhibit adenylate cyclase (AC), while $\mathrm{A}_{2 \mathrm{AR}}$ activate $\mathrm{AC}$ and promote CAMP production [25]. Activation of $A_{1 R}$ promoted the expression of pro-inflammatory factors, while $\mathrm{A}_{2 \mathrm{AR}}$ and $\mathrm{A}_{3 \mathrm{R}}$ inhibited the expression of pro-inflammatory factors.

\section{$A_{1}$ receptor}

Ponnoth Dovenia S et al. observed the effects of nebulized adenosine inhalation on vascular reactivity and inflammatory responses in $\mathrm{A}_{1 \mathrm{R}}$ knockout $\left(\mathrm{A}_{1} \mathrm{KO}\right)$ and corresponding wild-type $\left(\mathrm{A}_{1} \mathrm{WT}\right)$ mice and demonstrated that $\mathrm{A}_{1 \mathrm{R}}$ is a systemic pro-inflammatory factor [26]. Furthermore, the impact of adenosine on inflammatory regulation suggests that the adenosine receptors (ARs) can be activated or inactivated by the use of selective agonists or antagonists, which includes a potential contribution to inflammation-like diseases. Based on this theory, a newly synthesized in-house compound, 8-chloro-9-ethyl-2-phenethoxyadenine, was proposed as a candidate for inflammation therapy [27]. Studies of ophthalmologically relevant drug for $\mathrm{A}_{1 \mathrm{R}}$ have focused on retinal diseases [28], and because the drug did not pass phase III clinical trials [29], it was regretfully terminated. The $A_{1 R}$ antagonist has little prospect as a DED candidate because it increases Intraocular pressure in mice and rabbits [25].

\section{$A_{2 A}$ receptor}

$\mathrm{A}_{2 \mathrm{AR}}$ exerts its anti-inflammatory effects primarily by inhibiting the secretion of pro-inflammatory cytokines after the activation of inflammatory responses. Ko Il-Gyu proposes that $\mathrm{A}_{2 \mathrm{AR}}$ may be involved in the activation of the MAPK/ nuclear factor-kappa B (NF-kB) pathway as an important neuromodulator. NF-kB is stimulated by various factors such as cytokines and cellular stress, and activation (phosphorylation) of mitogen-activated protein kinase (MAPK)/NF-kB may promote the expression of multiple pro-inflammatory cytokines, resulting in inflammation, which is one of the mechanisms [30, 31]. In a mouse model of traumatic optic neuropathy (TON), Ahmad et al. reported that $\mathrm{A}_{2 \mathrm{AR}}$ agonist treatment significantly reduced the expression of inflammatory mediators (such as intercellular adhesion molecule-1, IL-6, and TNF- $\alpha$ ) and microglial marker IBA-1 [32].The protective role of $\mathrm{A}_{2 \mathrm{AR}}$ activation in diabetic retinal inflammation has been very well documented, and studies suggest that $\mathrm{A}_{2 \mathrm{AR}}$ agonists produce anti-inflammatory effects by blocking ERK activation and subsequent cytokine release [32, 33]. It is also a good inspiration for drug research in DED. Istradefylline, a specific $\mathrm{A}_{2 \mathrm{AR}}$ antagonist, decreased choroidal neovascularization [34]. US FDA approval of the istradefylline for treatment of Parkinson's disorders. This provides the safety profile of the $A_{2 A R}$ antagonist in human, and it facilitates to develop ophthalmic drugs about $\mathrm{A} 2$ for the future.

\section{$A_{3}$ receptor}

$\mathrm{A}_{3 \mathrm{R}}$ is involved in a number of different intracellular signaling pathways, and the $A_{3 R}$ was reported by Avni Isaac et al. to be highly upregulated in inflammatory cells [35]. Recently, the role of $A_{3 R}$ as a regulator of inflammation has become clear, making it an attractive target for the treatment of inflammatory diseases. $\mathrm{A}_{3 \mathrm{R}}$ is linked to the inhibition of adenylate cyclase and the regulation of MAPK pathways, leading to the regulation of transcription [36]. CF101 (N6-(3-iodobenzyl)-5'-Nmet-hylcarboxamidoadenosine), an $A_{3 R}$ agonist for the treatment of inflammatory diseases, downregulates the NF-kB signaling pathway, thereby inhibiting pro-inflammatory cytokines (TNF- $\alpha$, IL-6, IL-12) and macrophage inflammatory proteins (MIPs-1a, MIP2 ), resulting in apoptosis of inflammatory cells [37, 38]. CF101 exerted powerful anti-inflammatory effects in animal studies [39]. A randomized, multicenter, double-masked, placebo-controlled, parallel-group Phase II clinical study investigated the safety and efficacy of CF101 in the patients with moderate-to-severe DED. Patients aged $\geq 18$ years diagnosed with moderate to severe DED were selected, and they were randomly assigned to receive either a $1 \mathrm{mg}$ CF101 pill (oral) or matching vehicle-filled placebo pills twice daily for 12 weeks. Patients also received individually packaged preservative-free artificial tears as adjunctive therapy for up to eight times daily for the duration of the trial. Patients returned for clinical evaluation and new study drug supply at weeks $2,4,8$, and 12 , with a final followup evaluation at week 14 after 2 weeks of discontinuation. The results showed that $84.6 \%$ of patients had more than $25 \%$ improvement in corneal staining, and there were statistically significant differences between the CF101 and placebo treatment groups. The mean change in BUT from baseline was improved by CF101 over the placebo group. No serious adverse events were identified throughout the study. The most common adverse events included constipation, headache, palpitations, pruritus, abdominal pain, myalgia, fatigue, and dry mouth. The results of this study showed that oral administration of CF101 $1 \mathrm{mg}$ twice daily was well tolerated and demonstrated an excellent safety profile 
and sustained anti-inflammatory effect for up to 18 months. The anti-inflammatory effects of CF101 may influence the pathogenesis of distant disease and may serve as a novel approach to treating the cause of the disease, rather than just the symptoms [35]. Also, CF101 has demonstrated efficacy and safety in other inflammatory diseases such as psoriasis arthritis in clinical trials, and it is expected that oral small molecule drug CF101 will provide new prospects for the treatment of DED. However, DED is a chronic disease that lasts for a long time. Therefore, longer studies using CF101 in patients with DED are still needed to know long-term efficacy and safety of this drug.

\section{$\mathrm{P} 2 \mathrm{X}$ receptors in inflammation}

\section{$\mathrm{P} 2 \mathrm{X} 4$ receptor}

Inflammation and inflammasomes caused by P2X4R activation have also been implicated in the pathogenesis of DED. Components of NLRP3 are found in conjunctival capsular cells, which are punctate receptors that sense pathogens and other triggers, and are highly expressed in moist mucosa [40]. NLRP3 is a member of a multiprotein complex known as the NLRP3 inflammasome, which may activate IL-1b secretion and promote inflammation of the conjunctiva through the caspase-1 pathway. A study by Li Lin et al. showed that activation of P2X4R by ATP activates proinflammatory cytokines [41]. P2X4R may play a role in the initiation and activation of the NLRP3 inflammasome [40]. The above studies indicate that $\mathrm{P} 2 \mathrm{X} 4 \mathrm{R}$ activation may contribute to the development and worsening of DED. Therefore, it is important to inhibit its activation under inflammatory conditions. Minimizing the overexpression of P2X4R may be a target for the treatment of DED.

\section{P2X7 receptor}

$\mathrm{P} 2 \mathrm{X} 7 \mathrm{R}$ is an important target in the pathogenesis and treatment of DED. The ATP-gated P2X7R is a twice-transmembrane ion channel that is permeable to $\mathrm{Na}^{+}, \mathrm{K}^{+}$, and $\mathrm{Ca}^{2+}$. Activation of $\mathrm{P} 2 \mathrm{X} 7 \mathrm{R}$ activates the inflammasome and promotes the release of the proinflammatory cytokines IL-1 $\beta$ and IL-18 [42, 43]. When P2X7R is activated, cells are permeabilized with monovalent and divalent cations $\left(\mathrm{Na}^{+}, \mathrm{K}^{+}\right.$, $\mathrm{Ca}^{2+}$ ) and permeability. Rapid opening of potassium-selective channels results in a rapid decrease in intracellular potassium levels and the release of proinflammatory cytokines [44]. The inward flow of $\mathrm{Ca}^{2+}$ ions compensates for the outward flow of $\mathrm{K}^{+}$ions, resulting in P2X7R-induced intracellular $\mathrm{K}^{+}$ion loss or increased cytoplasmic $\mathrm{Ca}^{2+}$ ions thereby activating caspase- 1 . This activated caspase- 1 further leads to rapid activation and release of the pro-inflammatory cytokine IL-1 $\beta$. The subsequent increase in the concentration of IL- $1 \beta$ induces inflammation, which in turn induces other inflammatory mediators such as procysteine aspartate- 1 , nitric oxide synthase, cyclooxygenase- 2 , TNF- $\alpha$, phospholipase D, phospholipase A2, NF-kB, and MAPK [45]. Furthermore, P2X7R plays an important role in the regulation of wound healing by regulating corneal integrity and corneal epithelial cell migration [46]. DED is a disease of ocular surface inflammation and damage (including corneal epithelial damage) by multifactor, inflammation aggravates ocular surface damage, and damage aggravates ocular surface inflammation, forming a vicious circle. Based on the role of P2X7R in inflammation and corneal epithelial damage, it is worth to focus on the development of antagonists and agonists of P2X7R.

\section{$\mathrm{P} 2 \mathrm{Y}$ receptors in inflammation and mucin}

$\mathrm{P}_{2} \mathrm{Y}_{1}, \mathrm{P}_{2} \mathrm{Y}_{2}$, and $\mathrm{P} 2 \mathrm{Y}_{4}$ receptors are found in the corneal epithelium and endothelium [13, 14]. They can mediate $\mathrm{Ca}^{2+}$ mobilization after being activated by ATP or uridine 5 '-triphosphate (UTP), which results in downstream signaling to promote inflammation. According to the $\mathrm{G}$ protein coupling properties of P2YRs, $\mathrm{P} 2 \mathrm{Y}_{1 \mathrm{R}}, \mathrm{P} 2 \mathrm{Y}_{2 \mathrm{R}}$, and $\mathrm{P} 2 \mathrm{Y}_{4 \mathrm{R}}$ can be coupled to GQ to activate the phospholipase C (PLC)/IP3/ $\mathrm{Ca}^{2+}$ signaling pathway. $\mathrm{P}_{2} \mathrm{Y}_{1 \mathrm{R}}$ is involved in inflammatory sensitization [47]. High extracellular $\mathrm{NaCl}$ induces priming of the NLRP3 inflammasome in RPE cells, in part via $\mathrm{P}_{2} \mathrm{Y}_{1} \mathrm{R}$ signaling [48]. $\mathrm{P} 2 \mathrm{Y}_{2 \mathrm{R}}$ agonist induced IL-8 release and immunemediated inflammation of the mucosa characterized by the release of interleukin IL-8[49]. $\mathrm{P}_{2} \mathrm{Y}_{4 \mathrm{R}}$ signaling is involved in the production of pro-inflammatory cytokines via PI3K/Akt and ERK1/2-dependent pathways, and inhibition of $\mathrm{P} 2 \mathrm{Y}_{4 \mathrm{R}}$ expression significantly suppresses the production of proinflammatory cytokines [50]. Furthermore, G protein-coupled receptor kinase (GRK) 2 can induce and regulate the intensity and duration of inflammation [51]. Thus, the $\mathrm{P}_{2} \mathrm{Y}_{1}, \mathrm{P} 2 \mathrm{Y}_{2}$, and $\mathrm{P} 2 \mathrm{Y}_{4}$ receptors may be involved in the pathogenesis of inflammation in DED. On the other hand, $\mathrm{P}_{2} \mathrm{Y}_{2 \mathrm{R}}$ promotes mucus secretion from conjunctival gland vesicle cells by activating intracellular signals and specific transcription factors, and upregulates the expression of mucus genes [52]. Mucus proteins also reduce damage to mucosal epithelial cells in dry environments by lubricating the ocular surface and reducing friction. Mucin also plays an important role in DED due to its immune functions, such as strengthening the epithelial barrier, mediating various antimicrobial components, preventing pathogens from adhering to the ocular surface, and assisting in the removal of pathogenic microorganisms and cellular debris from the mucosal surface by aggregation [53, 54]. Studies have shown that purine $\mathrm{P} 2 \mathrm{Y}_{2 \mathrm{R}}$ promotes an increase in $\mathrm{Ca}^{2+}$ concentration in cell membranes, which results in the secretion of mucin [55, 56] (Fig. 2). Diquafosol tetrasodium acts as a $\mathrm{P} 2 \mathrm{Y}_{2 \mathrm{R}}$ agonist, activating $\mathrm{P} 2 \mathrm{Y}_{2 \mathrm{R}}$ on the ocular surface to improve the quantity and quality of tear fluid in patients 
Fig. $2 \mathrm{P}^{2} \mathrm{Y}_{1 \mathrm{R}}, \mathrm{P} 2 \mathrm{Y}_{2 \mathrm{R}}$, and $\mathrm{P} 2 \mathrm{Y}_{4 \mathrm{R}}$ are coupled to GQ and activate the phospholipase $\mathrm{C}$ (PLC)/IP3/Ca2 + signaling pathway, $\mathrm{P}_{2} \mathrm{Y}_{1}$ is involved in inflammatory sensitization, $\mathrm{P} 2 \mathrm{Y} 2$ receptor agonist induced IL-8 release, P2Y4R is involved in inflammatory cytokine production (top), $\mathrm{P}_{2} \mathrm{Y}_{2}$ receptor stimulated $\mathrm{Ca}^{2+}$ concentration increase in lacrimal gland follicles leading to mucin secretion (bottom)

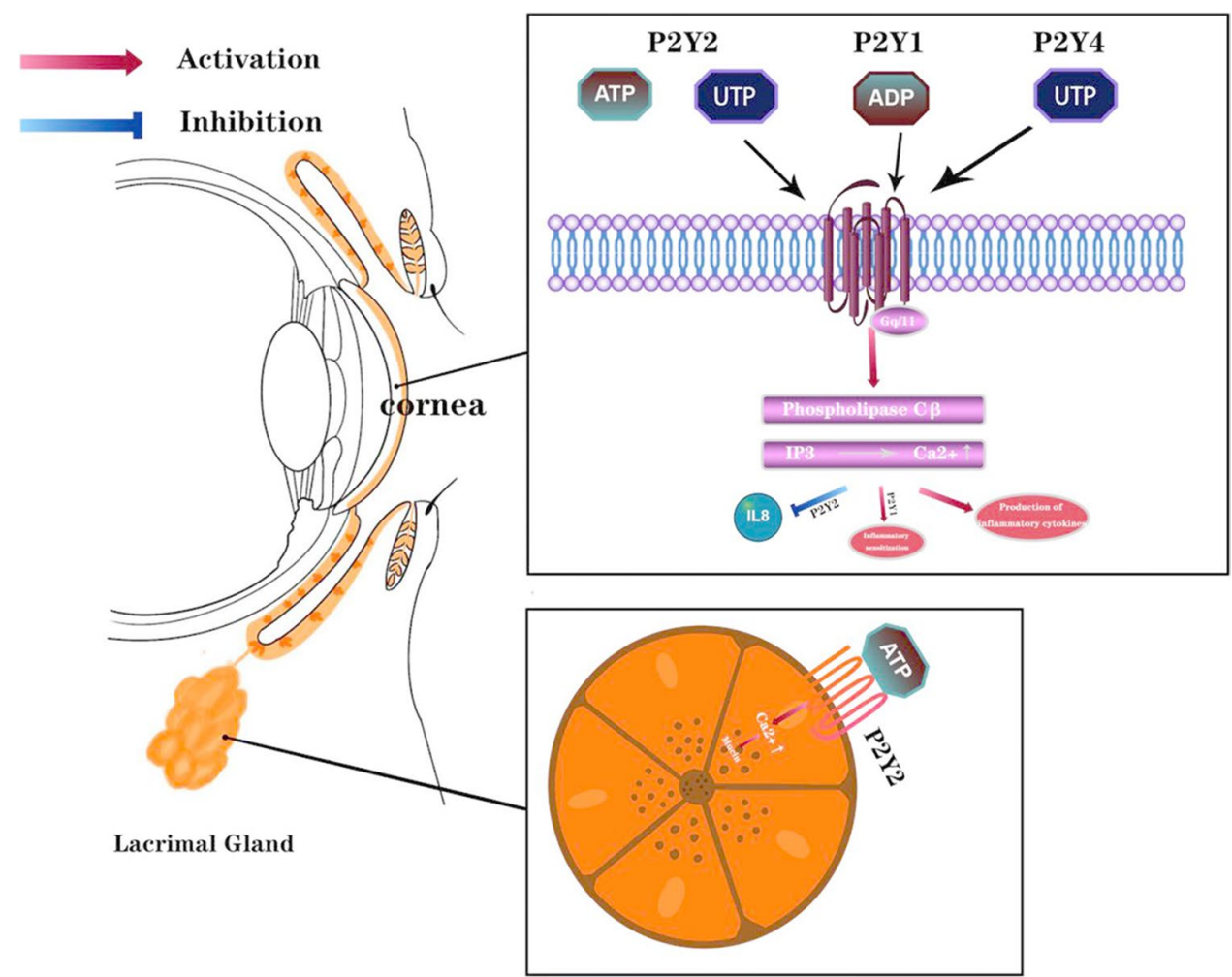

with DED through a novel mechanism that promotes aqueous humor transport, conjunctival epithelial mucus secretion, lipid production, and cell survival [57]. Nucleotides such as ATP and UTP are known to regulate processes such as tear secretion, wound healing, and prevention of surface infection. Diquafosol is a dinucleotide derivative of UTP [58]. Tadahiro Murakami et al. analyzed the ion transport system of the conjunctiva, another mechanism of tear secretion, using the Ussing chamber method. Their findings suggest that Diquafosol directly stimulates functional $\mathrm{P} 2 \mathrm{Y}_{2 \mathrm{R}}$ in conjunctival epithelial cells, increasing fluid flow and allowing $\mathrm{Cl}^{-}$secretion from the cell membrane to the mucosal side [59]. Furthermore, Diquafosol inhibits ERK-p90RSK-mediated apoptosis and enhances cell survival by inhibiting the NF-kB signaling pathway. It was also shown that Diquafosol has anti-ROS activity and that both ROS production and expression of the inflammatory mediator IL- $1 \mathrm{~b}$ and TNF- $\alpha$ were suppressed by Dictyostelium japonicum [57]. Overall, the role of P2YR in the molecular pathway of DED cannot be ignored. Systematic summary information is shown in Table 1.

\section{Conclusion and prospects}

This review summarizes the possible molecular mechanisms by different purinoceptors that mediate DED. $\mathrm{A}_{1}, \mathrm{~A}_{2 \mathrm{~A}}, \mathrm{~A}_{3}$, $\mathrm{P} 2 \mathrm{X} 4, \mathrm{P} 2 \mathrm{X} 7, \mathrm{P} 2 \mathrm{Y}_{1}, \mathrm{P}_{2} \mathrm{Y}_{2}$, and $\mathrm{P}_{2} \mathrm{Y}_{4}$ have been studied in ocular disease and inflammation, and the results of these studies are more valuable for mechanisms and therapy of DED. Other purines are not discussed in this review since their role in ocular disease and inflammation is rarely reported. Purinergic receptors act on inflammation from different targets and are effective in reducing inflammation and ocular surface damage in DED. Currently, the treatment for DED is mainly artificial tears and anti-inflammatory drugs. However, such anti-inflammatory drugs can cause ocular surface damage. Purinergic receptors play an active role in inflammation and ocular surface damage in DED. Therefore, focusing on purine receptors, the development of related drugs for the treatment of DED has broad prospects.

A new approach called polypharmacology has been gaining attention in the last decade. Polypharmacology is the use of a single drug to modulate multiple targets associated with a single disease pathway. In this regard, drugs that reach multiple sensitive targets (multi-targeted drugs) may have higher efficacy and can reduce the disadvantages usually associated with the use of combination therapies $[60,61]$. Bevan Nicola et al. designed an anti-inflammatory agent, GW328267X, an $\mathrm{A}_{2 \mathrm{AR}}$ agonist, and $\mathrm{A}_{3 \mathrm{R}}$ antagonist [62]. Hou Xiyan et al. designed a new series of dual-acting $h \mathrm{~A}_{2 \mathrm{AR}}$ agonists and $\mathrm{h} \mathrm{A}_{3 \mathrm{R}}$ antagonists for the treatment of inflammatory diseases [63]. Therefore, we believe that in the near future, multi-targeted drugs will be developed in the field of DED, and we can expect better effects, even the development of lubricant and purine combination drug dual component eye drops. In addition, since there 


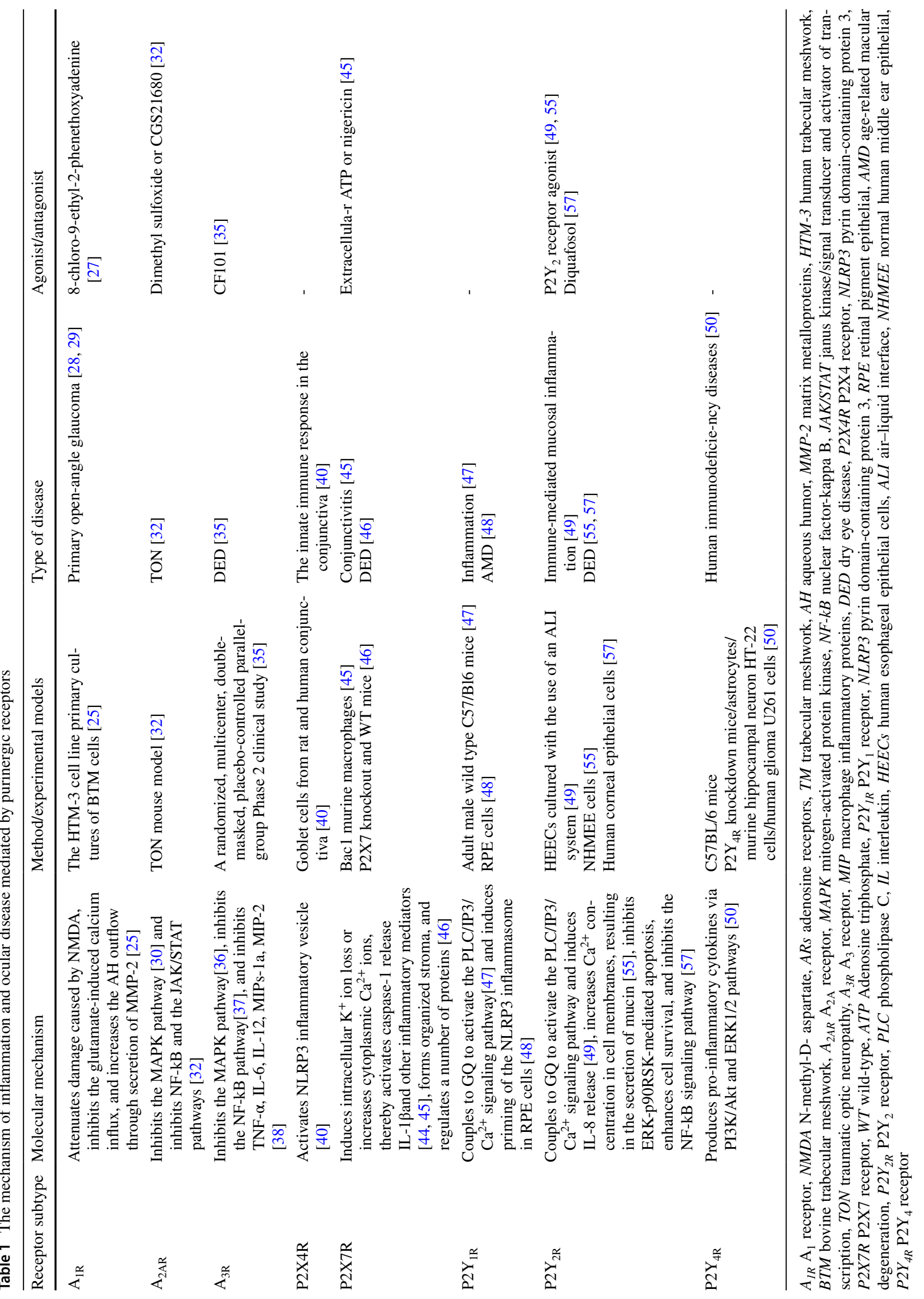


are so many ATP-releasing tissues and excess purine receptors in the eye, they may behave off-target, especially when released in excess in pathological or inflammatory conditions, probably due to the interaction of purine signaling systems in different ocular regions, leading to problems in ocular diseases; this is thought to be the case. This review not only contributes to a better understanding of purinergic receptors, but also provides a basis and direction for better treatment of DED in the future by altering the molecular mechanisms associated with purinergic receptors.

Funding This work was supported by grants from the Science and Technology Innovation Project of China Academy of Chinese Medical Sciences (CI2021A02608) and the Ten diseases and Ten drugs Project of Beijing Science and Technology Plan (Z161100001816006).

Data availability Not applicable.

\section{Declarations}

Conflicts of interest The authors declare no competing interests.

Ethical approval Not applicable.

Consent to participate Not applicable.

Open Access This article is licensed under a Creative Commons Attribution 4.0 International License, which permits use, sharing, adaptation, distribution and reproduction in any medium or format, as long as you give appropriate credit to the original author(s) and the source, provide a link to the Creative Commons licence, and indicate if changes were made. The images or other third party material in this article are included in the article's Creative Commons licence, unless indicated otherwise in a credit line to the material. If material is not included in the article's Creative Commons licence and your intended use is not permitted by statutory regulation or exceeds the permitted use, you will need to obtain permission directly from the copyright holder. To view a copy of this licence, visit http://creativecommons.org/licenses/by/4.0/.

\section{References}

1. Bron AJ, De Paiva CS, Chauhan SK et al (2017) TFOS DEWS II pathophysiology report. Ocul Surf 15:438-510

2. Bradley JL, Ozer Stillman I, Pivneva I et al (2019) Dry eye disease ranking among common reasons for seeking eye care in a large US claims database. Clin Ophthalmol 13:225-232

3. Burnstock G (2017) Purinergic signalling: therapeutic developments. Front Pharmacol 8:661

4. Alves M, Smith J, Engel T (2019) Differential expression of the metabotropic P2Y receptor family in the cortex following status epilepticus and neuroprotection via P2Y1 antagonism in mice. Front Pharmacol 10:1558

5. Tsubota K, Fukagawa K, Fujihara T et al (1999) Regulation of human leukocyte antigen expression in human conjunctival epithelium. Invest Ophthalmol Vis Sci 40:28-34

6. Pisella PJ, Brignole F, Debbasch C et al (2000) Flow cytometric analysis of conjunctival epithelium in ocular rosacea and keratoconjunctivitis sicca. Ophthalmol 107:1841-1849
7. De Paiva CS, Pflugfelder SC (2008) Rationale for anti-inflammatory therapy in dry eye syndrome. ArqBras Oftalmol 71:89-95

8. Luo L, Li DQ, Doshi A, Farley W, Corrales RM, Pflugfelder SC (2004) Experimental dry eye stimulates production of inflammatory cytokines and MMP-9 and activates MAPK signaling pathways on the ocular surface. Invest Ophthalmol Vis Sci 4:4293-4301

9. Acera A, Rocha G, Vecino E et al (2008) Inflammatory markers in the tears of patients with ocular surface disease. Ophthalmic Res 40:315-321

10. Pflugfelder SC, Farley W, Luo L et al (2005) Matrix metalloproteinase-9 knockout confers resistance to corneal epithelial barrier disruption in experimental dry eye. Am J Pathol 166:61-71

11. Yoon KC, De Paiva CS, Qi H et al (2007) Expression of Th-1 chemokines and chemokine receptors on the ocular surface of C57BL/6 mice: effects of desiccating stress. Invest Ophthalmol Vis Sci 48:2561

12. Sanderson J, Dartt DA, Trinkaus-Randall V et al (2014) Purines in the eye: recent evidence for the physiological and pathological role of purines in the RPE, retinal neurons, astrocytes, Muller cells, lens, trabecular meshwork, cornea and lacrimal gland. Exp Eye Res 127:270-279

13. Pintor J, Sanchez-Nogueiro J, Irazu M et al (2004) Immunolocalisation of $\mathrm{P} 2 \mathrm{Y}$ receptors in the rat eye. Purinergic Signalling 1:83-90

14. Mankus C, Rich C, Minns M et al (2011) Corneal epithelium expresses a variant of $\mathrm{P} 2 \mathrm{X}(7)$ receptor in health and disease. PloS one 6:e28541

15. Cowlen MS, Zhang VZ, Warnock L et al (2003) Localization of ocular P2Y2 receptor gene expression by in situ hybridization. Exp Eye Res 77:77-84

16. Baldini C, Rossi C, Ferro F et al (2013) The P2X7 receptorinflammasome complex has a role in modulating the inflammatory response in primary Sjogren's syndrome. J Intern Med 274:480-489

17. Han Y, Shao Y, Lin Z et al (2012) Netrin-1 simultaneously suppresses corneal inflammation and neovascularization. Invest Ophthalmol Vis Sci 53:1285-1295

18. Ochaion A, Bar-Yehuda S, Cohen S et al (2009) The anti-inflammatory target $\mathrm{A}(3)$ adenosine receptor is over-expressed in rheumatoid arthritis, psoriasis and Crohn's disease. Cell Immunol 258:115-122

19. Guzman-Aranguez A, Santano C, Martin-Gil A et al (2013) Nucleotides in the eye: focus on functional aspects and therapeutic perspectives. J Pharmacol Exp Ther 345:331-341

20. Fiebich BL, Akter S, Akundi RS (2014) The two-hit hypothesis for neuroinflammation: role of exogenous ATP in modulating inflammation in the brain. Front Cell Neurosci 8:260

21. Peral A, Domínguez-Godínez CO, Carracedo G, Pintor J (2008) Therapeutic targets in dry eye syndrome. Drug News Perspect 21:166-76

22. Donnenfeld E, Pflugfelder SC (2009) Topical ophthalmic cyclosporine: pharmacology and clinical uses. Surv Ophthalmol 2009 54:321-38

23. Pintor J, Peral A, Hoyle CH et al (2002) Effects of diadenosine polyphosphates on tear secretion in New Zealand white rabbits. J Pharmacol Exp Ther 300:291-297

24. Tauber J, Davitt WF, Bokosky JE et al (2004) Double-masked, placebo-controlled safety and efficacy trial of diquafosol tetrasodium (INS365) ophthalmic solution for the treatment of dry eye. Cornea 23:784-792

25. Spinozzi E, Baldassarri C, Acquaticci L et al. (2021) Adenosine receptors as promising targets for the management of ocular diseases. Medicinal chemistry research : an international journal for rapid communications on design and mechanisms of action of biologically active agents: $1-18$ 
26. Ponnoth DS, Nadeem A, Tilley S et al (2010) Involvement of A1 adenosine receptors in altered vascular responses and inflammation in an allergic mouse model of asthma. American journal of physiology. Heart circ physiol 299:H81-87

27. Marti Navia A, Dal Ben D, Lambertucci C et al. (2020) Adenosine receptors as neuroinflammation modulators: role of A1 agonists and A2A antagonists. Cells 9

28. Huang Z, Xie N, Illes P et al (2021) From purines to purinergic signalling: molecular functions and human diseases. Signal Transduct Target Ther 6:162

29. Jacobson KA, Tosh DK, Jain S et al (2019) Historical and current adenosine receptor agonists in preclinical and clinical development. Front Cell Neurosci 13:124

30. Ko IG, Jin JJ, Hwang L et al (2021) Adenosine A2A receptor agonist polydeoxyribonucleotide alleviates interstitial cystitis-induced voiding dysfunction by suppressing inflammation and apoptosis in rats. J Inflamm Res 14:367-378

31. Ye SS, Tang Y, Song JT (2021) ATP and adenosine in the retina and retinal diseases. Frontiers pharmacol 12:654445

32. Ahmad S, Fatteh N, El-Sherbiny NM et al (2013) Potential role of A2A adenosine receptor in traumatic optic neuropathy. J Neuroimmunol 264:54-64

33. Elsherbiny NM, Naime M, Ahmad S et al (2013) Potential roles of adenosine deaminase- 2 in diabetic retinopathy. Biochem Biophys Res Commun 436:355-361

34. SorensonChristine M, Yong-Seok S, ZaitounIsmail S et al (2021) Caffeine inhibits choroidal neovascularization through mitigation of inflammatory and angiogenesis activities. Front Cell Dev Biol 9:737426

35. Avni I, Garzozi HJ, Barequet IS et al (2010) Treatment of dry eye syndrome with orally administered CF101: data from a phase 2 clinical trial. Ophthalmol 117:1287-1293

36. Jacobson KA, Merighi S, Varani K et al (2018) A3 adenosine receptors as modulators of inflammation: from medicinal chemistry to therapy. Med Res Rev 38:1031-1072

37. Szabo C, Scott GS, Virag L et al (1998) Suppression of macrophage inflammatory protein (MIP)-1alpha production and collagen-induced arthritis by adenosine receptor agonists. Br J Pharmacol 125:379-387

38. Fishman P, Bar-Yehuda S, Madi L et al (2006) The PI3K-NFkappaB signal transduction pathway is involved in mediating the anti-inflammatory effect of IB-MECA in adjuvant-induced arthritis. Arthritis Res Ther 8:R33

39. Rath-Wolfson L, Bar-Yehuda S, Madi L et al (2006) IB-MECA, an $\mathrm{A} 3$ adenosine receptor agonist prevents bone resorption in rats with adjuvant induced arthritis. Clin Exp Rheumatol 24:400-406

40. Mcgilligan VE, Gregory-Ksander MS, Li D et al (2013) Staphylococcus aureus activates the NLRP3 inflammasome in human and rat conjunctival goblet cells. PloS one 8:e74010

41. Li L, Zou Y, Liu B et al (2020) Contribution of the P2X4 receptor in rat hippocampus to the comorbidity of chronic pain and depression. ACS Chem Neurosci 11:4387-4397

42. Janks L, Sprague RS, Egan TM (2019) ATP-gated P2X7 receptors require chloride channels To promote inflammation in human macrophages. J Immunol 202:883-898

43. Savina A, Paola F, Susanna A et al (2021) Novel P2X7 antagonist ameliorates the early phase of ALS disease and decreases inflammation and autophagy in SOD1-G93A mouse model. Int J Mol Sci 22:19

44. Chu YX, Zhang Y, Zhang YQ et al (2010) Involvement of microglial P2X7 receptors and downstream signaling pathways in longterm potentiation of spinal nociceptive responses. Brain Behav Immun 24:1176-1189

45. Mehta N, Kaur M, Singh M et al (2014) Purinergic receptor P2X(7): a novel target for anti-inflammatory therapy. Bioorg Med Chem 22:54-88
46. Mayo C, Ren R, Rich C et al (2008) Regulation by P2X7: epithelial migration and stromal organization in the cornea. Invest Ophthalmol Vis Sci 49:4384-4391

47. Malin SA, Molliver DC (2010) Gi- and Gq-coupled ADP (P2Y) receptors act in opposition to modulate nociceptive signaling and inflammatory pain behavior. Mol Pain 6:21

48. Prager P, Hollborn M, Steffen A et al (2016) P2Y1 receptor signaling contributes to high salt-induced priming of the NLRP3 inflammasome in retinal pigment epithelial cells. PloS one 11:e0165653

49. Wu L, Oshima T, Fukui H et al (2017) Adenosine triphosphate induces P2Y2 activation and interleukin-8 release in human esophageal epithelial cells. J Gastroenterol Hepatol 32:1341-1347

50. Zhou F, Liu X, Gao L et al (2019) HIV-1 Tat enhances purinergic $\mathrm{P} 2 \mathrm{Y} 4$ receptor signaling to mediate inflammatory cytokine production and neuronal damage via PI3K/Akt and ERK MAPK pathways. J Neuroinflammation 16:71

51. Walker AK, Kavelaars A, Heijnen CJ et al (2014) Neuroinflammation and comorbidity of pain and depression. Pharmacol Rev 66:80-101

52. Terakado K, Yogo T, Kohara Y et al (2014) Conjunctival expression of the P2Y2 receptor and the effects of 3\% diquafosol ophthalmic solution in dogs. Vet $\mathrm{J} 202: 48-52$

53. Mantelli F, Argueso P (2008) Functions of ocular surface mucins in health and disease. Curr Opin Allergy Clin Immunol 8:477-483

54. Montes-Mico R, Cervino A, Ferrer-Blasco T et al (2010) The tear film and the optical quality of the eye. Ocul Surf 8:185-192

55. Choi JY, Shin JH, Kim JL et al (2005) P2Y2 agonist induces mucin secretion via $\mathrm{Ca} 2+-$ and inositol 1,4,5-triphosphatedependent pathway in human middle ear epithelial cells. Hear Res 209:24-31

56. Kreda SM, Okada SF, Van Heusden CA et al (2007) Coordinated release of nucleotides and mucin from human airway epithelial Calu-3 cells. J Physiol 584:245-259

57. Park JH, Moon SH, Kang DH et al (2018) Diquafosol sodium inhibits apoptosis and inflammation of corneal epithelial cells via activation of Erk1/2 and RSK: in vitro and in vivo dry eye model. Invest Ophthalmol Vis Sci 59:5108-5115

58. Crooke A, Guzman-Aranguez A, Peral A et al (2008) Nucleotides in ocular secretions: their role in ocular physiology. Pharmacol Ther 119:55-73

59. Murakami T, Fujihara T, Horibe $Y$ et al (2004) Diquafosol elicits increases in net $\mathrm{Cl}$ - transport through $\mathrm{P} 2 \mathrm{Y} 2$ receptor stimulation in rabbit conjunctiva. Ophthalmic Res 36:89-93

60. Anighoro A, Bajorath J, Rastelli G (2014) Polypharmacology: challenges and opportunities in drug discovery. J Med Chem 57:7874-7887

61. Lavecchia A, Cerchia C (2016) In silico methods to address polypharmacology: current status, applications and future perspectives. Drug Discovery Today 21:288-298

62. Bevan N, Butchers PR, Cousins R et al (2007) Pharmacological characterisation and inhibitory effects of $(2 \mathrm{R}, 3 \mathrm{R}, 4 \mathrm{~S}, 5 \mathrm{R})-2-(6-$ amino-2-\{[(1S)-2-hydroxy-1-(phenylmethyl)ethyl]amino\}-9H-purin -9-yl)-5-(2-ethyl-2H-tetrazol-5-yl)tetrahydro-3,4-furandiol, a novel ligand that demonstrates both adenosine $\mathrm{A}(2 \mathrm{~A})$ receptor agonist and adenosine A(3) receptor antagonist activity. Eur J Pharmacol 564:219-225

63. Hou X, Majik MS, Kim K et al (2012) Structure-activity relationships of truncated $\mathrm{C} 2$ - or $\mathrm{C} 8$-substituted adenosine derivatives as dual acting $\mathrm{A}(2) \mathrm{A}$ and $\mathrm{A}(3)$ adenosine receptor ligands. J Med Chem 55:342-356

Publisher's note Springer Nature remains neutral with regard to jurisdictional claims in published maps and institutional affiliations. 